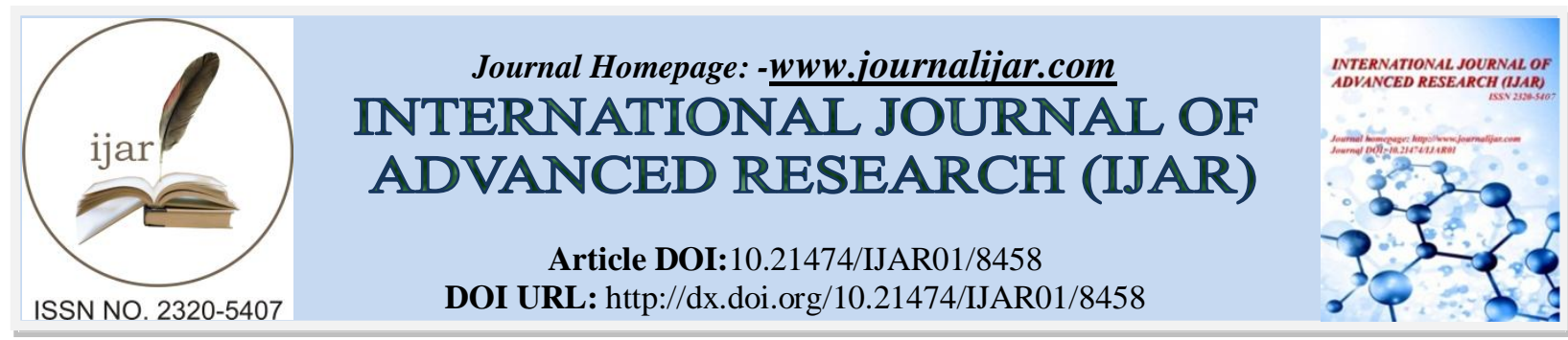

RESEARCH ARTICLE

\title{
EVALUATION OF FARMERS' PERCEPTION AND ACTION LEARNING FROM FARMERS FIELD DAYS DEMONSTRATION ON USING BRIQUETTE UREA FERTILIZER IN HYBRID MAIZE PRODUCTION.
}

\author{
Thant Lwin Oo ${ }^{1}$,Than Da Min ${ }^{2}$, KyawKyaw Win ${ }^{3}$ and Mie Mie Aung ${ }^{4}$. \\ 1. Research based PhD student, Yezin Agricultural University, Myanmar. \\ 2. Professor, Agronomy, Yezin Agricultural University, Myanmar. \\ 3. Pro-Rector, Yezin Agricultural University, Myanmar. \\ 4. Professor, Plant Breeding, Physiology and Ecology, Yezin Agricultural University, Myanmar.
}

\section{Manuscript Info}

\section{Manuscript History}

Received: 02 December 2018

Final Accepted: 04 January 2019

Published: February 2019

Key words:-

Urea deep placement, Briquette urea, Field day, Survey questionnaire.

\begin{abstract}
Best management practices for the crop are focused mainly on effectiveness of fertilizer. Being small holder farmers, fertilizer is the most expensive input for them and their ultimate goal is to get maximum profit with minimum input cost. To know the effect of urea deep placement (UDP) technology, experiments were conducted during rainy season and winter season, 2017. The four field days $\left(8^{\text {th }}\right.$ and $9^{\text {th }}$ August, 2017 and $26^{\text {th }}$ and $28^{\text {th }}$ February, 2018) were organized and conducted on the Department of Agricultural Research, Yezin and Tatkone Agricultural Research Farm. The neighbouring townships farmers are invited to attend the field days and farmers were randomly selected from the field day attendees. Knowledge of farmers about maize production practices and UDP technology being promoted were recorded in a short survey structured questionnaire. From the survey questionnaires, most farmers are using urea fertilizer for $\mathrm{N}$ source and 56.81 to $113.62 \mathrm{~kg} \mathrm{~N} \mathrm{ha}^{-1}$ is the common rate for them. They usually split the amount of urea into 2 to 3 times. Farmers do not know UDP method with briquette form. This study highlighted that by using the entire $\mathrm{N}$ in the form of briquette at basal showed better performance with respect to yield and nitrogen uptake efficiency.
\end{abstract}

Copy Right, IJAR, 2019,. All rights reserved.

\section{Introduction:-}

Nitrogen is the main nutrient for yield of maize. Maize yield in Myanmar is considered to be relatively low due in part to inadequate fertilizer use, especially nitrogen $(\mathrm{N})$. Being small holder farmers, fertilizer is the most expensive input for them and their ultimate goal is to get maximum profit with minimum input cost. Thus, fertilizer management is important as it contributes to increasing crop yield. Nowadays, research efforts have been made to improve the efficiency of synthetic $\mathrm{N}$ fertilizers and to reduce their impact on the environment. Fertilizer deep placement with briquette urea is the proven technology in Bangladesh and sub-Saharan Africa countries more recently in Myanmar that can increase the yield of transplanted lowland rice and maize by 15-20 percent with less use of urea (up to 40 percent) compared to broadcast application of urea (IFDC, 2013; 2016).

Corresponding Author:-Thant LwinOo.

Address:-Research based PhD student, Yezin Agricultural University, Myanmar. 
On-farm field days are a traditional educational tool used by Agricultural Extension Agents and Researchers. The aim of the field day is to stimulate farmers' interest in adoption of innovations and to convince them of the point and practicability of the technologies being demonstrated. Field days provide the right platforms for farmers to share information within specific environments (Amudaviet.al., 2009). The objective of the field day, as stated by Gibbons and Schroeder (1983) is: "to bring farmers together on a site to enable them to gain knowledge and skills in a relaxed environment, create awareness of improved technologies and show the results of the technologies, and stimulate adoption of improved technologies by farmers so as to improve yield". One of the most common ways to evaluate the impact of on-farm field days is with a post-event questionnaire.

To know the effect of UDP technology, experiments were conducted during rainy season, and winter season, 2017. The rainy season experiment was evaluated on three $\mathrm{N}$ rates $71.27,118.78$ and $166.29 \mathrm{~kg} \mathrm{~N}^{-1}$ with briquette form and prilled form of urea for Yezin Hybrid maize-10 production. The winter season experiment focused on three placement pattern (between rows, between plants and between plants and rows) of briquette urea and prilled urea with the same rate (166.29 $\mathrm{kg} \mathrm{N} \mathrm{ha}^{-1}$ ) for Yezin Hybrid maize-10 production. Each season experiment was carried out at two locations, the Department of Agricultural Research, Yezin and Tatkone Agricultural Research Farm. The first field days in both Yezin and Tatkone were held in August, 2017 and the second field days were held in February, 2018 for both sites. The purpose of this study was to access the impact of field days on knowledge of fertilizer deep placement with briquette urea technology by farmers in maize production.

\section{Materials and Methods:-}

The four field days were organized and conducted at the Department of Agricultural Research, Yezin and Tatkone Agricultural Research Farm. The neighbouring townships farmers are invited to attend the field days. The rainy season filed day was held on $8^{\text {th }}$ August 2017 at Yezin, DAR and $9^{\text {th }}$ August 2017 at Tatkone Agricultural Research Farm. There were total 51 respondents; 23 farmers from Pyinmana townships and 28 farmers from Tatkone townships. The winter season filed day was held on $26^{\text {th }}$ February 2018 at Yezin, DAR and $28^{\text {th }}$ February 2018 at Tatkone Agricultural Research Farm. There were 54 respondents; 27 attendees each from Pyinmana and Tatkone townships. Knowledge of farmers about maize production practices and UDP technology being promoted were recorded in a short survey structured questionnaire. The interviews were conducted by research technician from the Department of Agricultural Research. The questionnaire items coded were designed in Microsoft Excel. The data entered was exported to SPSS (Version 16.0). Descriptive statistics such as the mean, minimum, maximum, percentages and frequencies were computed to describe the scio-economic characteristics, agronomic and information on farmer perception rate on UDP with briquette. Preference percentage of attendees for treatment was done and analyzed.

\section{Results and Discussion:- Demographic Characters}

Table 1 shows the number of respondents and their respective villages. The average age of the attendees from Pyinmana townships was 50 years with the range of 28 to 75 years. The average schooling year of them was 8 with the minimum schooling year of 5 to maximum 16 years. The family size of them was ranged from 2 to 8 and their owned acreage was ranged from 2 to 17 acres with the average farm size was 8 acres (Table 2). The average age of the attendees from Tatkone townships was 50 years ranging from 28 to 65 years. Their education level was minimum 5 years and maximum was 15 years with the average education level of 8 years. Their family size of them was ranging from 3 to 10 and their farm size ranging from 1.25 to 18 acres (Table 3).

Table 4 shows the number of respondents and their respective villages. The ages of the attendees were between 29 to 76 years old in Pyinmana townships and between 20 to 71 years old in Tatkone townships. The educational background of the attendees varies from 1 to 15 years in Pyinmana and 4 to 13 years in Tatkone townships. The family size of the attendees ranged from 2 to 9 in both townships. The ownership of farm land varied from 2 to 25 acres in Pyinmana attendees and 2.5 to 25 acres in Tatkone attendees. The average values of each item were presented in Table 5 and 6.

\section{Maize production practices used by attendees from Pyinmana and Tatkone townships}

The maize production practices used by attendees are shown in Table 7 and 8 . The majority of the attendees $86.96 \%$ from Pyinmana are using the plant distance of 9 to 12 inches and row distance of 30 inches in rainy season maize production. They are using closer spacing in winter season, thus $77.8 \%$ and $66.7 \%$ of the Pyinmana attendees are 
using the plant distance of 9 to 12 inches and row distance of 30 inches in winter season maize production. The most of the attendees $89.29 \%$ from the Tatkone had practiced the plant distance of 9 to 12 inches and $75 \%$ had practiced the row distance of 30 inches for rainy season maize production. For winter season maize production, more than $50 \%$ of the attendees from Tatkone areas are using the plant distance of 6 to 8 inches and row distance of 18 inches. All attendees from both locations were done intercultivation for both rainy and winter season production. For controlling of pest and diseases, all farmers done the control measures in rainy season production in both areas but $25.9 \%$ and $33.3 \%$ of the Pyinmana and Tatkone attendees respectively done the control of pest and diseases for their winter season production. Thinning was done only $25 \%$ in the Tatkone areas and $60.87 \%$ in the Pyinmana areas for rainy season production. For the winter season production, thinning was done $63 \%$ in Pyinmana and $74.1 \%$ in Tatkone areas. The weed control for rainy season maize production, $56.5 \%$ of the Pyinmana attendees and $67.9 \%$ of the Tatkone attendee had practiced by hand weeding. Both hand weeding and application of herbicide was practiced by $34.8 \%$ of Pyinmana attendees and $21.4 \%$ by Tatkone attendees. The weed control for the winter season production, 55.6\% and 74.1\% attendees of Pyinmana and Tatkone townships were done by hand weeding. Based on the survey results, it can be concluded that most farmers know well about the agronomic practices for maize production.

Use of mineral fertilizer and FYM in attendee areas

The use of mineral fertilizer and FYM for the rainy season maize production of attendee areas are presented in Table 9. Urea fertilizer is the most widely use fertilizer $82.61 \%$ and $89.28 \%$ of the attendee from Pyinmana and Tatkone townships respectively. The second most fertilizer used by the maize producing farmer is compound fertilizer of $\mathrm{N}$, $\mathrm{P}$ and K (47.8\% and $64.29 \%$ of the Pyinmana and Tatkone attendees respectively). Very few attendee farmers, $13.04 \%$ and $17.88 \%$ of the Pyinmana and Tatkone are using the triple super phosphate fertilizer and similar result was in the Potash fertilizer uses $13.04 \%$ of attendee in Pyinmana and $7.14 \%$ in Takone. The attendees from the Pyinmana areas are not using FYM but $28.57 \%$ of attendee from Tatkone areas is using FYM in their rainy season maize production.

Table 10 shows the use of mineral fertilizer and FYM for the winter season maize production of attendee areas. 96.3\% and $92.6 \%$ of attendees from Pyinmana and Tatkone townships used urea fertilizer. The compound fertilizer of N,P and $\mathrm{K}$ is the second rank in farmer use commodity; $44.4 \%$ of attendees from Pyinmana and $81.5 \%$ of attendees from Tatkone are using compound fertilizer. Few farmers are using triple super phosphate fertilizer (29.6\% and $11.1 \%$ of attendees from Pyinmana and Tatkone areas) and Potash fertilizer (14.8\% and $7.4 \%$ of attendees from Pyinmana and Tatkone areas). FYM application for the winter season maize production, $33.3 \%$ of attendees from Pyinmana and 55.6\% of attendees from Tatkone are using FYM.

These survey results pointed that they are not using $\mathrm{P}$ and $\mathrm{K}$ fertilizer and there is still need to educate farmers on balanced fertilizer effects to get the high yield in their production.

\section{Urea application practices on maize Production}

Table 11 shows the urea application practices of attendees in Pyinmana and Tatkone areas for their rainy season maize production. For rate of urea application, most farmers are using at the rate of $123.50 \mathrm{~kg}$ per hectare in both areas $(34.78 \%$ of the attendees from Pyinmana and $64.29 \%$ of the attendees from Tatkone). For the time of urea application, few farmers are using urea as basal fertilizer (30.4\% in Pyinmana and 10.7\% in Tatkone). The proportion of $30.4 \%$ of attendees from Pyinmana and $46.43 \%$ of attendees from Tatkone are using urea as side dressing at 14 DAS. Almost half of the attendees $43.49 \%$ and $46.43 \%$ from Pyinmana and Tatkone areas are using urea as split application at 21 DAS. Most of the attendees (47.82\% from Pyinmana and 67.86\% from Tatkone) are using urea as side dressing at 35 DAS. The rate of side dressing urea ranged from 30.88 to $123.50 \mathrm{~kg} \mathrm{ha}^{-1}$. The early side dress at 14 DAS and 21 DAS, farmers are mostly use low dose of urea $61.75 \mathrm{~kg} \mathrm{ha}^{-1}$.

Table 12 shows the urea application practices of attendees in Pyinmana and Tatkone areas for their winter season maize production. For their winter maize, most attendees (40.7\%) from Tatkone areas are using urea at the rate of $247 \mathrm{~kg} \mathrm{ha}^{-1}$ but $33.3 \%$ of attendees from the Pyinmana are using urea at the rate of $123.5 \mathrm{~kg} \mathrm{ha}^{-1}$. Seventeen $(62.6 \%)$ out of 27 attendees from Pyinmana areas and 12(44.4\%) out of 27 attendees from Tatkone areas using urea at basal with the rate of 61.75 to $185.25 \mathrm{~kg} \mathrm{ha}^{-1}$. Eleven (40.7\%) out of 27 attendees from Pyinmana areas and 5(18.5\%) out of 27 attendees from Tatkone areas using urea as side dressing at 14 DAS with the rate of $61.75 \mathrm{~kg}^{-1}$ in Pyinmana areas and 61.75 to $123.50 \mathrm{~kg} \mathrm{ha}^{-1}$ in Tatkone areas. Fifteen $(55.5 \%)$ out of 27 attendees from Pyinmana areas and $13(48.1 \%)$ out of 27 attendees from Tatkone areas are using urea as side dressing at 21 DAS with the rate of 61.75 
to $123.50 \mathrm{~kg} \mathrm{ha}^{-1}$. For the side dressing of urea at $35 \mathrm{DAS}, 59.2 \%$ and $55.5 \%$ of the attendees from Pyinmana and Tatkone areas are using urea with the rate of 61.75 to $123.50 \mathrm{~kg} \mathrm{ha}^{-1}$.

\section{Knowledge of attendees on importance of urea and its application methods}

All attendees from Pyinmana and Tatkone townships knew well that urea fertilizer is important for yield of rainy season and winter season maize production. They were not used fertilizer deep placement method and they do not know the briquette form of urea fertilizer (Table 13 and 14). On the rainy season field days, after observation on plant performance of briquette urea application plots, $56.52 \%$ and $85.71 \%$ of attendees from Pyinmana and Tatkone areas respectively were decided that briquette form of urea is more effective than ordinary prilled urea in urea application. The most of the attendees $82.6 \%$ from Pyinmana areas and $92.8 \%$ of attendees from Tatkone areas want to use briquette urea in their maize production. After the observation on the winter season field days, $55.6 \%$ and 74.07\% of attendees from Pyinmana and Tatkone areas thought that briquette form is more effective than prilled urea and they are willing to use briquette form of urea than ordinary prilled urea.

\section{Preference percentage on different treatment of rate and form of urea application}

The identification and observation was made from plots of three different $\mathrm{N}$ rates $(71.27,118.78$ and $166.29 \mathrm{~kg} \mathrm{~N}$ $\mathrm{ha}^{-1}$ ) with two forms (prilled and briquette) in Yezin Hybrid Maize-10 production which was conducted in rainy season. The preference percentage was recorded after observation. The attendees from Tatkone $(42.86 \%)$ and attendees from Pyinmana (21.74\%) preferred briquette urea with the rate of $118.78 \mathrm{~kg} \mathrm{Nha}^{-1}$. The most of the attendees $(78.26 \%)$ from Pyinmana and $57.14 \%$ of attendees from Tatkone areas preferred the briquette urea application with the rate of $166.29 \mathrm{~kg} \mathrm{Nha}^{-1}$. None of the attendee from Tatkone townships chose the prilled urea treated plots. Only $4.35 \%$ to $8.7 \%$ of the attendees from the Pinmana townships showed the preference on prilled urea treated plots (Table 15).

\section{Preference percentage on different placement pattern and form of urea application}

On the decision to use of briquette urea and urea placement pattern displayed during the field day farmers were asked which treatment is the best displayed during the field day. The three placement patterns of urea application (between plants, between rows and between plants and rows) with two form of urea (briquette and prilled) were displayed in the Yezin Hybrid maize-10 production. The same rate of urea $166.29 \mathrm{~kg} \mathrm{~N}^{-1}{ }^{-1}$ was used and the results are represented in Table 16. Twelve (44.4\%) farmers from Pyinmana areas and fifteen $(55.6 \%)$ farmers from Tatkone responded that they liked most to use briquette urea application at between plant and between rows displayed during the field day. Some of the attendees (22.22\%) from Pyinmana and TatkoneTatkone areas preferred the briquette urea application and placement site at between plants. Only $3.7 \%$ of the attendees from the Pinmana and Tatkone townships showed the preference on prilled urea treated plots.

\section{Conclusion:-}

This study provided better understanding of nitrogen use efficiency and the effectiveness of fertilizer by using briquette with deep placement method. Best management practices for the crop are focused mainly on effectiveness of fertilizer. Effectiveness is maximized when the most appropriate nutrient sources are applied at the right place, time and rate. As $\mathrm{N}$ fertilizer is the main element for increasing the yield of maize, almost all farmers are using $\mathrm{N}$ fertilizer in their production. From the survey questionnaires, most farmers are using urea fertilizer for $\mathrm{N}$ source and 56.81 to $113.62 \mathrm{~kg} \mathrm{~N} \mathrm{ha}^{-1}$ is the common rate for them. They usually split the doses of urea into 2 to 3 times. The highest preference percentage was recorded from $166.29 \mathrm{~kg} \mathrm{~N}^{-1}$ briquette urea treated plots and briquette placement at both between rows and between plants. This study highlighted that by using the entire $\mathrm{N}$ in the form of briquette at basal showed better performance with respect to yield and nitrogen uptake efficiency.

Table 1:-Number of attendee on field days at Yezin, DAR and Tatkone Research Farm (August, 2017)

\begin{tabular}{|l|c|l|c|}
\hline \multicolumn{2}{|c|}{ Pyinmana } & \multicolumn{2}{c|}{ Tatkone } \\
\hline Name of Village & No. of Respondents & Name of Village & No. of Respondents \\
\hline Kyankhin & 1 & Kinpontan & 1 \\
\hline Laythar & 3 & Kynbo & 3 \\
\hline Nyungpin & 6 & Latpankone & 1 \\
\hline Sintaegy & 1 & Latpantan & 12 \\
\hline Sintaeky & 1 & Shaukkone & 12 \\
\hline
\end{tabular}




\begin{tabular}{|l|c|l|c|}
\hline Thapyaepin & 3 & ShweMyo & 1 \\
\hline Thayetta & 1 & Shweooedaung & 4 \\
\hline Yonepin & 6 & & \\
\hline Ywatha & 1 & & $\mathbf{2 8}$ \\
\hline Total & $\mathbf{2 3}$ & & \\
\hline
\end{tabular}

Table 2:-Demographic characteristics of attendee households from Pyinmana townships (August, 2017)

\begin{tabular}{|l|c|c|c|c|c|}
\hline Item & Unit & Average & Minimum & Maximum & SD \\
\hline Age & Year & 50 & 28 & 75 & 13 \\
\hline Schooling Year & Year & 8 & 5 & 16 & 3 \\
\hline Family Size & No. & 5 & 2 & 8 & 2 \\
\hline Farm size & Acre & 8 & 2 & 17 & 4 \\
\hline
\end{tabular}

Table 3:-Demographic characteristics of attendee households from Tatkone townships (August, 2017)

\begin{tabular}{|l|c|c|c|c|c|}
\hline Item & Unit & Average & Minimum & Maximum & SD \\
\hline Age & Year & 50 & 28 & 65 & 11 \\
\hline Schooling Year & Year & 8 & 5 & 15 & 3 \\
\hline Family Size & No. & 6 & 3 & 10 & 2 \\
\hline Farm size & Acre & 7 & 1.25 & 18 & 4.4 \\
\hline
\end{tabular}

Table 4:-Number of attendee on field days at Yezin, DAR and Tatkone Research Farm (February, 2018)

\begin{tabular}{|l|c|l|c|}
\hline \multicolumn{2}{|c|}{ Pyinmana } & \multicolumn{2}{c|}{ Tatkone } \\
\hline Name of Village & No. of Respondents & Name of Village & No. of Respondents \\
\hline Nyaung Pin Thar & 4 & Anawyada & 5 \\
\hline Sanesarpin & 1 & Kinponton & 2 \\
\hline Sipinthayar & 6 & Kyarthaeai & 2 \\
\hline Thapyaepin & 4 & Magyepin & 1 \\
\hline Tharyarkone & 8 & Naungthinka & 1 \\
\hline Thayethamain & 1 & Nyaunglunt & 1 \\
\hline Thayetkone & 1 & Shakone & 1 \\
\hline Theyetthamane & 1 & Shartaw & 5 \\
\hline Yonepin & 1 & Shaukone & 3 \\
\hline & & Sinthay & 3 \\
\hline & & Thapyaethar & $\mathbf{2 7}$ \\
\hline
\end{tabular}

Table 5:-Demographic characteristics of attendee households from Pyinmana townships (February, 2018)

\begin{tabular}{|l|c|c|c|c|c|}
\hline Item & Unit & Average & Minimum & Maximum & SD \\
\hline Age & Year & 52 & 29 & 76 & 11 \\
\hline Schooling Year & Year & 7 & 1 & 15 & 3 \\
\hline Family Size & No. & 5 & 2 & 9 & 2 \\
\hline Farm size & Acre & 8 & 2 & 25 & 7 \\
\hline
\end{tabular}

Table 6:-Demographic characteristics of attendee households from Tatkone townships (February, 2018)

\begin{tabular}{|l|c|c|c|c|c|}
\hline Item & Unit & Average & Minimum & Maximum & SD \\
\hline Age & Year & 50 & 20 & 71 & 14 \\
\hline Schooling Year & Year & 9 & 4 & 13 & 2 \\
\hline Family Size & No. & 5 & 2 & 9 & 2 \\
\hline Farm size & Acre & 8 & 2.5 & 25 & 5 \\
\hline
\end{tabular}


Table 7:-The distribution of maize production practices used by attendee from Pyinmana and Tatkone areas (August, 2017)

\begin{tabular}{|c|c|c|c|c|}
\hline \multirow{2}{*}{$\begin{array}{l}\text { Items } \\
\text { Plant Distance }\end{array}$} & \multicolumn{2}{|l|}{ Pyinmana(n=23) } & \multicolumn{2}{|l|}{ Tatkone(n=28) } \\
\hline & Frequency & $\%$ & Frequency & $\%$ \\
\hline 6-8 inches & 3 & 13.04 & 3 & 10.71 \\
\hline 9-12 inches & 20 & 86.96 & 25 & 89.29 \\
\hline Total & 23 & & 28 & \\
\hline \multicolumn{5}{|l|}{ Row Distance } \\
\hline 8 inches & 0 & 0 & 1 & 3.57 \\
\hline 18 inches & 3 & 13.04 & 6 & 21.43 \\
\hline 30 inches & 20 & 86.96 & 21 & 75.00 \\
\hline Total & 23 & & 28 & \\
\hline \multicolumn{5}{|l|}{ Thinning } \\
\hline Yes & 14 & 60.87 & 7 & 25 \\
\hline No & 9 & 39.13 & 21 & 75 \\
\hline Total & 23 & & 26 & \\
\hline \multicolumn{5}{|l|}{ Intercultivation } \\
\hline Yes & 23 & 100 & 28 & 100 \\
\hline No & 0 & 0 & 0 & 0 \\
\hline Total & 23 & & 28 & \\
\hline \multicolumn{5}{|l|}{ Pest\& Disease Control } \\
\hline Yes & 23 & 100 & 28 & 100 \\
\hline No & 0 & 0 & 0 & 0 \\
\hline Total & 23 & & 28 & \\
\hline \multicolumn{5}{|l|}{ Weed Control } \\
\hline Hand weeding & 13 & 56.5 & 19 & 67.9 \\
\hline Herbicide & 2 & 8.7 & 3 & 10.7 \\
\hline Hand weeding+ Herbicide & 8 & 34.8 & 6 & 21.4 \\
\hline Total & 23 & & 28 & \\
\hline
\end{tabular}

Table 8:-The distribution of maize production practices used by attendee from Pyinmana and Tatkone areas (February, 2018)

\begin{tabular}{|c|c|c|c|c|}
\hline Items & Pyin & & Tatkc & \\
\hline Plant Distance & Frequency & $\%$ & Frequency & $\%$ \\
\hline 6-8 inches & 6 & 22.2 & 15 & 55.6 \\
\hline 9-12 inches & 21 & 77.8 & 12 & 44.4 \\
\hline Total & 27 & & 27 & \\
\hline Row Distance & & & & \\
\hline 18 inches & 9 & 33.3 & 14 & 51.9 \\
\hline 30 inches & 18 & 66.7 & 13 & 48.1 \\
\hline Total & 27 & & 27 & \\
\hline Thinning & & & & \\
\hline Yes & 17 & 63 & 20 & 74.1 \\
\hline No & 10 & 37 & 7 & 25.9 \\
\hline Total & 26 & & 27 & \\
\hline Intercultivation & & & & \\
\hline Yes & 27 & 100 & 27 & 100 \\
\hline No & 0 & 0 & 0 & 0 \\
\hline Total & 27 & & 27 & \\
\hline Pest\& Disease Co & & & & \\
\hline Yes & 7 & 25.9 & 9 & 33.3 \\
\hline No & 20 & 74.1 & 18 & 66.7 \\
\hline Total & 27 & & 27 & \\
\hline Weed Control & & & & \\
\hline
\end{tabular}




\begin{tabular}{|l|c|c|c|c|}
\hline Hand weeding & 15 & 55.6 & 20 & 74.1 \\
\hline Herbicide & 6 & 22.2 & 6 & 22.2 \\
\hline Hand weeding+ Herbicide & 6 & 22.2 & 1 & 3.7 \\
\hline Total & 27 & & 27 & \\
\hline
\end{tabular}

Table 9:-Use of mineral fertilizer and FYM application in attendee areas (August, 2017)

\begin{tabular}{|l|c|c|c|c|}
\hline \multirow{2}{*}{ Fertilizer } & \multicolumn{4}{|c|}{ Respondent } \\
\cline { 2 - 5 } & \multicolumn{2}{|c|}{ Pyinmana $(\mathrm{n}=23)$} & Tatkone $(\mathrm{n}=28)$ \\
\cline { 2 - 5 } & Frequency & Percentage & Frequency & Percentage \\
\hline Urea & 19 & 82.61 & 25 & 89.28 \\
\hline Compound & 11 & 47.8 & 18 & 64.29 \\
\hline Triple Super Phosphate & 3 & 13.04 & 5 & 17.88 \\
\hline Potash & 3 & 13.04 & 2 & 7.14 \\
\hline Manure (FYM) & 0 & 0 & 8 & 28.57 \\
\hline
\end{tabular}

Table 10:-Use of mineral fertilizer and FYM application in attendee areas (February, 2018)

\begin{tabular}{|l|c|c|c|c|}
\hline \multirow{2}{*}{ Fertilizer } & \multicolumn{4}{|c|}{ Respondent } \\
\cline { 2 - 5 } & \multicolumn{2}{|c|}{ Pyinmana $(\mathrm{n}=27)$} & \multicolumn{2}{c|}{ Tatkone $(\mathrm{n}=27)$} \\
\cline { 2 - 5 } & Frequency & Percentage & Frequency & Percentage \\
\hline Urea & 26 & 96.3 & 25 & 92.6 \\
\hline Compound & 12 & 44.4 & 22 & 81.5 \\
\hline Triple Super Phosphate & 8 & 29.6 & 3 & 11.1 \\
\hline Potash & 4 & 14.8 & 2 & 7.4 \\
\hline Manure (FYM) & 9 & 33.3 & 15 & 55.6 \\
\hline
\end{tabular}

Table 11:-The distribution of urea application practices on maize production used by attendee from Pyinmana and

Tatkone areas (August, 2017)

\begin{tabular}{|c|c|c|c|c|}
\hline \multirow{2}{*}{$\begin{array}{l}\text { Items } \\
\text { Rate per Hectare } \\
\end{array}$} & \multicolumn{2}{|c|}{$\operatorname{Pyinmana}(n=23)$} & \multicolumn{2}{|c|}{ Tatkone(n=28) } \\
\hline & Frequency & $\%$ & Frequency & $\%$ \\
\hline & 1 & 4.35 & 0 & 0 \\
\hline $123.50 \mathrm{~kg}$ & 8 & 34.78 & 18 & 64.29 \\
\hline $185.25 \mathrm{~kg}$ & 3 & 13.04 & 0 & 0 \\
\hline $247.00 \mathrm{~kg}$ & 4 & 17.39 & 3 & 10.71 \\
\hline $308.75 \mathrm{~kg}$ & 2 & 8.70 & 0 & 0.00 \\
\hline $370.50 \mathrm{~kg}$ & 1 & 4.35 & 4 & 14.29 \\
\hline Total & 20 & & 25 & \\
\hline \multicolumn{5}{|l|}{ Basal application } \\
\hline $61.75 \mathrm{~kg}$ & 3 & 13.04 & 1 & 3.57 \\
\hline $123.50 \mathrm{~kg}$ & 4 & 17.39 & 2 & 7.14 \\
\hline Total & 7 & & 3 & \\
\hline \multicolumn{5}{|l|}{14 DAS application } \\
\hline $30.88 \mathrm{~kg}$ & 0 & 0.00 & 4 & 14.29 \\
\hline $61.75 \mathrm{~kg}$ & 3 & 13.04 & 3 & 10.71 \\
\hline $123.50 \mathrm{~kg}$ & 4 & 17.39 & 6 & 21.43 \\
\hline Total & 7 & & 13 & \\
\hline \multicolumn{5}{|l|}{21 DAS application } \\
\hline $30.88 \mathrm{~kg}$ & 1 & 4.35 & 4 & 14.29 \\
\hline $61.75 \mathrm{~kg}$ & 5 & 21.74 & 1 & 3.57 \\
\hline $92.63 \mathrm{~kg}$ & 2 & 8.70 & 0 & 0.00 \\
\hline $123.50 \mathrm{~kg}$ & 2 & 8.70 & 8 & 28.57 \\
\hline Total & 10 & & 13 & \\
\hline \multicolumn{5}{|l|}{35 DAS application } \\
\hline $30.88 \mathrm{~kg}$ & 1 & 4.35 & 0 & 0.00 \\
\hline
\end{tabular}




\begin{tabular}{|l|c|c|c|c|}
\hline $61.75 \mathrm{~kg}$ & 7 & 30.43 & 7 & 25.00 \\
\hline $92.63 \mathrm{~kg}$ & 2 & 8.69 & 0 & 0.00 \\
\hline $123.50 \mathrm{~kg}$ & 7 & 4.35 & 12 & 42.86 \\
\hline Total & $\mathbf{1 7}$ & & $\mathbf{1 9}$ & \\
\hline
\end{tabular}

Table 12:-The distribution of urea application practices on maize production used by attendee from Pyinmana and Tatkone areas (February, 2018)

\begin{tabular}{|c|c|c|c|c|}
\hline \multirow{2}{*}{$\begin{array}{l}\text { Items } \\
\text { Rate per Hectare }\end{array}$} & \multicolumn{2}{|c|}{ Pyinmana(n=27) } & \multicolumn{2}{|c|}{ Tatkone(n=27) } \\
\hline & Frequency & $\%$ & Frequency & $\%$ \\
\hline $61.75 \mathrm{~kg}$ & 1 & 3.7 & 1 & 3.7 \\
\hline $123.50 \mathrm{~kg}$ & 9 & 33.3 & 9 & 33.3 \\
\hline $185.25 \mathrm{~kg}$ & 7 & 25.9 & 2 & 7.4 \\
\hline $247.00 \mathrm{~kg}$ & 6 & 22.2 & 11 & 40.7 \\
\hline $308.75 \mathrm{~kg}$ & 3 & 11.1 & 0 & 0 \\
\hline $370.50 \mathrm{~kg}$ & 1 & 3.7 & 2 & 7.4 \\
\hline Total & 27 & & 25 & \\
\hline \multicolumn{5}{|l|}{ Basal application } \\
\hline $61.75 \mathrm{~kg}$ & 7 & 25.9 & 2 & 7.4 \\
\hline $123.50 \mathrm{~kg}$ & 7 & 25.9 & 8 & 29.6 \\
\hline $185.25 \mathrm{~kg}$ & 3 & 11.1 & 2 & 7.4 \\
\hline Total & 17 & & 12 & \\
\hline \multicolumn{5}{|l|}{14 DAS application } \\
\hline $61.75 \mathrm{~kg}$ & 11 & 40.7 & 3 & 11.1 \\
\hline $123.50 \mathrm{~kg}$ & 0 & 0 & 2 & 7.4 \\
\hline Total & 11 & & 5 & \\
\hline \multicolumn{5}{|l|}{21 DAS application } \\
\hline $61.75 \mathrm{~kg}$ & 11 & 40.7 & 7 & 25.9 \\
\hline $123.50 \mathrm{~kg}$ & 4 & 14.8 & 6 & 22.2 \\
\hline Total & 15 & & 13 & \\
\hline \multicolumn{5}{|l|}{35 DAS application } \\
\hline $61.75 \mathrm{~kg}$ & 8 & 29.6 & 5 & 18.5 \\
\hline $123.50 \mathrm{~kg}$ & 8 & 29.6 & 10 & 37.0 \\
\hline Total & 16 & & 15 & \\
\hline
\end{tabular}

Table 13:-Percentage of attendee who knew the importance of urea and application methods in maize production areas of Pyinmana and Tatkone (August, 2017)

\begin{tabular}{|l|c|c|c|c|}
\hline Questions & \multicolumn{2}{|c|}{ Pyinmana } & \multicolumn{2}{|c|}{ Tatkone } \\
\cline { 2 - 5 } & Yes & No & Yes & No \\
\hline 1. Does the farmer know the important of urea fertilizer? & 100 & 0 & 100 & 0 \\
\hline 2. Does the farmer know the briquette form of urea? & 0 & 100 & 7.2 & 92.8 \\
\hline 3. Does the farmer think the briquette form of urea is more effective than prilled & 56.52 & 43.48 & 85.71 & 14.29 \\
\hline 4. Does the farmer want to use briquette form of urea in maize production? & 82.6 & 17.4 & 92.8 & 7.2 \\
\hline 5. Does the farmer know the fertilizer deep placement method? & 0 & 100 & 0 & 100 \\
\hline
\end{tabular}

Table 14:-Percentage of attendee who knew the importance of urea and application methods in maize production areas of Pyinmana and Tatkone (February, 2018)

\begin{tabular}{|l|c|c|c|c|}
\hline Questions & \multicolumn{2}{|c|}{ Pyinmana } & \multicolumn{2}{c|}{ Tatkone } \\
\cline { 2 - 5 } & Yes & No & Yes & No \\
\hline 1. Does the farmer know the important of urea fertilizer? & 96.3 & 3.7 & 100 & 0 \\
\hline 2. Does the farmer know the briquette form of urea? & 100 & 0 & 0 & 100 \\
\hline 3. Does the farmer think the briquette form of urea is more effective than & 55.6 & 44.4 & 74.07 & 25.93 \\
\hline 4. Does the farmer want to use briquette form of urea in maize & 96.3 & 3.7 & 25 & 92.6 \\
\hline 5. Does the farmer know the fertilizer deep placement method? & 0 & 100 & 0 & 100 \\
\hline
\end{tabular}


Table 15:-Preference percentage of attendee on Different treatment of Rate and Form of Urea application in maize production (August, 2017)

\begin{tabular}{|l|c|c|c|c|}
\hline \multirow{2}{*}{ Rate and Form of Urea Fertilizer } & \multicolumn{4}{|c|}{ Respondent } \\
\cline { 2 - 5 } & \multicolumn{2}{|c|}{ Pyinmana $(\mathrm{n}=23)$} & \multicolumn{2}{c|}{ Tatkone $(\mathrm{n}=28)$} \\
\cline { 2 - 5 } & Frequency & Percentage & Frequency & Percentage \\
\hline Prilled Urea 71.27 kg N ha' & 1 & 4.35 & 0 & 0 \\
\hline Prilled Urea $118.78 \mathrm{~kg} \mathrm{~N} \mathrm{ha}^{-1}$ & 1 & 4.35 & 0 & 0 \\
\hline Prilled Urea $166.29 \mathrm{~kg} \mathrm{~N} \mathrm{ha}^{-1}$ & 2 & 8.7 & 0 & 0 \\
\hline Briquette Urea $71.27 \mathrm{~kg} \mathrm{~N} \mathrm{ha}^{-1}$ & 0 & 0 & 0 & 0 \\
\hline Briquette Urea $118.78 \mathrm{~kg} \mathrm{~N} \mathrm{ha}^{-1}$ & 5 & 21.74 & 12 & 52.86 \\
\hline Briquette Urea $166.29 \mathrm{~kg} \mathrm{~N} \mathrm{ha}^{-1}$ & 18 & 78.26 & 16 & 57.14 \\
\hline
\end{tabular}

Table 16:-Preference percentage of attendee on different treatment of placement pattern and form of urea application in maize production (February, 2018)

\begin{tabular}{|l|c|c|c|c|}
\hline \multirow{2}{*}{ N Rate (166.29 $\mathrm{kg} \mathrm{N} \mathrm{ha}^{-1}$ )and Form of Urea Fertilizer } & \multicolumn{4}{|c|}{ Respondent } \\
\cline { 2 - 5 } & \multicolumn{2}{|c|}{ Pyinmana (n=27) } & \multicolumn{2}{c|}{ Tatkone (n=27 ) } \\
\cline { 2 - 5 } & Frequency & Percentage & Frequency & Percentage \\
\hline Between plants with Briquette Urea & 6 & 22.22 & 6 & 22.2 \\
\hline Between rows with Briquette Urea & 8 & 29.63 & 5 & 18.5 \\
\hline Between plants and rows with Briquette Urea & 12 & 44.4 & 15 & 55.6 \\
\hline Between plants with Prilled Urea & 1 & 3.7 & 0 & 0 \\
\hline Between rows with Prilled Urea & 0 & 0 & 1 & 3.7 \\
\hline Between plants and rows with Prilled Urea & 0 & 0 & 0 & 0 \\
\hline
\end{tabular}

\section{References:-}

1. Amudavi, D. M., Khan, Z. R., Wanyama, J. M., Midega, C. A. O., Pittchar, J., Hassanali, A., \& Pickett, J. A. (2009). Evaluation of farmers' field days as a dissemination tool for push-pull technology in Western Kenya. Crop Protection, 28(3), 225-235.

2. Gibbons, M. J., \& Schroeder, R. (1983). Agricultural Extension. Washington, D.C.: Peace Corps, Information Collection \& Exchange.

3. IFDC, (2013). Annual Report 2013, International Fertilizer Development Center, Alabama, USA

4. IFDC, (2016). Annual Report 2016, International Fertilizer Development Center, Alabama, USA. 